\title{
Criticism of Educational Cynicism
}

\author{
Victor R. Imakaev* \\ Perm State National Research University \\ 15 Bukireva Str., Perm, 614990, Russia
}

Received 18.02.2017, received in revised form 27.11.2017, accepted 07.12.2017

The article investigates the phenomenon of "educational cynicism" - an attitude towards "enlightened negativity" frequently seen among school teachers and university professors. Since this attitude is usually manifested in rejection, opposition and accusation, the article is structured with binary oppositions, manifested in words and actions of the neo-tribe of "educational cynics."

Keywords: cynicism (contemporary) and cynicism (philosophy), somatics and thinking, fear and interest, theory and practice, selection and choice, messianism and professionalism, worldview and educational offer.

DOI: $10.17516 / 1997-1370-0180$.

Research area: philosophy.

\begin{abstract}
"Cynicism is an enlightened false consciousness. This is modernized unhappy consciousness, over which the Enlightenment has already worked not without effect and at the same time in vain .... Rich and wretched at the same time, this consciousness already feels immune to any criticism of ideologies; its falsity is already capable of striking back" (Sloterdijk, 2009: 33).

"We do not know what to teach children. We have poor vision of how our knowledge will be useful to them in the future. There is nothing surprising that they perceive a section from the textbook or another theory presented during a lesson as a bowl of soup to be swallowed in order to comfort their mother and do something more interesting" (Andreeva, 2016).
\end{abstract}

\section{Introduction}

The title of this article in many respects echoes with the title of Peter Sloterdijk's book Critique of Cynical Reason (Sloterdijk, 2009), published 33 years ago. According to Sloterdijk, "enlightened negativity" lies at the heart of educational cynicism. Without accepting what is happening, a cynical teacher makes negativity a part of his/her personality, a part of him/herself. In many respects this is promoted by the fact that in the process of reflecting about them they believe themselves to be enlightened people. We understand educational cynicism as a total of attitudes of a type of a teacher (a school teacher

(C) Siberian Federal University. All rights reserved

* Corresponding author E-mail address: ivr65@rambler.ru 
or a university professor) that is common in mass education: it is a negative enlightened and, therefore, authoritative attitude toward students, a school (university) administration, the Ministry of Education (or other state education agencies), innovative educational projects, individual education, parents and their colleagues. This is the same type that is indignant over the next reforms of the Ministry, which believes that only God knows algebra to "5", they themselves know it to "4" (what follows that is well known), and the one who, in response to an innovative proposal, sorrowfully exclaims "But we are only checked by the USE results!"

Let us note that Sloterdijk distinguishes between cynicism (contemporary) and cynicism (philosophy). From the time of Diogenes cynicism (philosophy) is an active protest and, at the same time, a mockery. A travesty of the cynics' claim to power. A travesty of the disintegration of theory and practice and of the imaginary dominance of theorists over practice. Sloterdijk drew a parallel between cynicism (philosophy) and modern alternative movements. We believe that innovative pedagogical movements in this context are manifestations of educational cynicism (philosophy) (or can become such).

The danger of cynicism (philosophy) criticism is the transformation of cynicism critics into cynics. This is facilitated by the desire to finally seize the power and arrange "everything differently" in education. In order not to fall into a performative contradiction (Habermas, 2000: 126), educational cynicism (philosophy), as we argue, should not seek to occupy key positions in the hierarchical structure of cynical pedagogical knowledge. The emergence and legitimization of new organized nature of those who share the ideas of individual education and organized natures overcoming the hierarchical structure of pedagogical knowledge is the most important task of the innovative pedagogical community.
The further text of our work is devoted to various aspects of criticizing educational cynicism that are often loosely related to each other. We did not set the task of presenting these aspects consistently, systematically and fundamentally. If you like, these are sketches, fragments, various aspects of travesty, surprise and criticism.

\section{Thinking vs somatics}

A typical situation for any audience. Children (or adults - university professors or school teachers) received a "non-standard task". A few minutes passed in the agonizing "thinking". Everyone is trying to "solve this task in the mind"; while physically the person is doing nothing. Hi/she is not drawing and not trying to depict what is given in the statement, not, at least, trying to change seats to someone and discuss the ideas for the solution.

There is a deliberate disruption in thinking and somatics in the entire structure of mass education, at schools and universities. To think means to sit still and wrinkle your forehead. During the lessons, children sit still, just like their teachers do at the conference. Their physical movements are in no way connected with thinking; these are rather instinctive body movements. The leg became numb, so you need to change the position.

To move does not mean to think. When at the regional competition "The Teacher of the Year" on the third minute of the lesson a physical education teacher suggested the children "to think and discuss", one of the jury's members opened his mouth wide in amazement.

Let me note - it is not about physical education breaks. During these breaks, as a teacher thinks, children stop thinking and are stretching up their bodies to start thinking still again.

It is all about the fact that the thought action caused by the body movement or the body 
movement mediated by thinking are not perceived as a necessary attribute of the educational process. Dexterity is one thing. This is a physical education teacher's business. Flexibility of mind is different. This is, for example, a mathematics teacher's business.

These attitudes are dominant. In general education there are virtually no practices that presuppose the interdependent activity of the intellect and the body. Not surprisingly that in almost any class, there is a differentiation between "sickly nerds" and strong and healthy "half-wits".

Practices of "immobile thinking" and "thoughtless movement" characteristic of school and university contrast sharply with the numerous practices that are widely spread outside the mass education. A software programmer thinks, and his thought is expressed in dextrous and quick movement of his/her fingers on the keyboard. Pianists often have a state that is characterized as "fingers and hands think". In order to play tennis well and to drive a car it is necessary to think and act physically coherently. Finally, to play computer games, you need to have the dexterity determined by quick thinking. This is what children know for sure.

We will express a working hypothesis that in this dissociation of thinking and bodily movement, the body "wins". It is the constrained somatics that is looking for its way out - pinching a neighbor and running around during a break. After a physical education lesson, we noticed that children do not rush to "solve tasks" or discuss a problematic issue in history.

\section{Theory vs Practice}

First, theory, and then (if there is enough time and, as a rule, it is not enough) practice. Despite a huge number of studies, projects and purchased sets of laboratory equipment, this educational cynicism is dominant. "Quasi" educational slogan "Knowledge is power" is in its basis. The majority of teachers are absolutely sure: "when it is told, it means it is acquired". A school or university student is a snail that must carry a library of "knowledge" with him/her. Store is no sore, knowledge will be useful "one day".

A specific consequence of this attitude is a widespread way of actions of social actors and officials of different persuasions: "There is a problem - we need to introduce a new academic subject". Adults do not comply with the laws let's introduce the subject "Fundamentals of Law" at school. There is the problem of moral decadence - let's introduce the subject "Fundamentals of Secular Ethics".

The cynicism of this attitude is obvious. If the theory is not mediated by the activity of "here and now", it will not be internalized. This is confirmed not only by pedagogical experiments. This is a phenomenologically observable reality for any school teacher and university professor. The next piece of theoretical knowledge will be washed away by a powerful information flow, which is introduced both by a sms from a girlfriend, a post in a social network, a dispute with a friend, and a watched film. Nothing separates the content of the section about arthropods in this information flow.

What are the reasons for the dominance of this attitude?

To recognize practice as a priority means to give up a part of one's own power. Practice is always situational, it is eventful, and it can lead to a lot of unplanned things: to questions, to breakdowns and to physical activity. Managing practice is much more difficult than managing the process of "writing down" or "listening" to theory.

The second reason is the supposed hierarchical nature of the pedagogical knowledge structure itself. We will consider this aspect of 
educational cynicism a little bit later, meanwhile we will note an interesting fact: when discussing innovative pedagogical ideas with teachers, they proudly exclaim: "We are not theoreticians, we are practitioners!" It turns out that in relation to pedagogical action a teacher "imagines" him/ herself to be a practitioner who does not need "theoreticians", but in relation to the discipline taught by the teacher - a "theorist" who does not offer practice to school or university students!

\section{Mathematics vs fine arts}

In general education, there is an actual division of subjects into "important" and secondary. The "important" ones include mathematics, the Russian language, physics and history (everyone can continue the list); "secondary" subjects include fine arts, music and dance classes. These subjects are in the curriculum of primary school, and the first years of general school. In high school they are not required as compulsory ones. There are areas of art that generally, as a rule, are not studied photography and cinema. What is the reason? The argument "they will have to pass the USE in mathematics" is a weak argument in this case - this state of affairs existed in general education even before the introduction of the USE. In Russian universities, of engineering orientation for example, you will not find dance classes, music, painting and art photography in the principal educational programme. "Leg twitching" safely migrated to extracurricular activities, to additional education.

"Mathematics", they will say to you, "organizes your mind. And what can your dance classes give? “... Dance classes organize the body. Singing allows training your voice. Painting develops a sense of composition and good taste. In other words there are a lot of arguments in defense of the thesis that a person, regardless of how his/ her life will continue, needs all these wonderful disciplines. And, despite the fact that these arguments are recognized as fair, the division of subjects into "important" and "secondary" ones remains. Of course, no one officially calls them "second-class subjects", but informally "everyone understands everything". What is the reason for this "double consciousness?" The answer is obvious. These disciplines are contrary to the educational cynicism orientations described above. They involve a combination of thinking, experiencing and somatics. Their study is impossible without the priority of practice.

Dance classes and music can introduce alien phenomena into mass education: pleasure and interest that is not mediated by pragmatics (it is not necessary to pass the USE). They are generally based on interest. It makes sense (if you take on this business) to offer them as elective courses. Someone will choose classics (waltz, tango and foxtrot), someone - social dances, someone - rap and someone rock.

Running a little bit ahead: it is impossible to teach these subjects without being in line with the zone of a child's nearest development. First we will train pure solo singing, and then we will try to sing "a due voci".

\section{Selection vs choice}

In recent years, the opposition of "choice/ selection" is a fundamental opposition, which, as we see it, determines the development/stagnation of Russian education. Most educators, whether they are teachers and school administration, university professors or employees of educational authorities, consciously or unconsciously resist the ideas of choosing curricula, constructing individual educational trajectories and the very concept of individualization in general.

Most schools that started implementing the model of individual curricula returned to more familiar and simple models of profile groups and even profile classes. Universities report on 
the variability of individual student curricula, while at the beginning of each semester students sign the same curriculum "chosen" by them. The choice space construction in primary school faces the same problems. There are thousands of reasons, excuses and arguments, according to which it is either difficult or impossible to implement the principle of choice in different educational organizations.

The concept of choice, according to which a school or university student has the right to decide at what level, from whom and with whom to study, is confronted with the concept of selection, which suggests that adults, teachers and administration determine themselves who to select for studying any (the same for all) curriculum.

Supporters of the concept of choice believe in the student's subjectness. They sincerely believe that the student has the right to choose (including erroneously) any part of curriculum; that to a certain extent this right enforcement makes the student a subject of his/her own educational activity.

The supporters of the concept of choice trust subjectness. If a main school student chooses a training group or a short-term course "in step with" his/her friend, if a student has chosen an academic discipline that, as someone seems, "they do not need", it is their choice, they must exhaust this choice up to the end, to understand its limited nature. The older a student becomes, the greater freedom of choice he/she should be given.

The supporters of the selection concept do not trust students' subjectness. They consider them (students) incapable of making any particular educational decisions. "We know better what they need", we know better what kind of education should be given - this is the slogan of the selection concept supporters.

To stop subjectness being only an ideology, it is necessary, at least, to learn to notice its manifestations in students' activity. Most supporters of the "selection" concept do not believe in subjectness, because they do not see it. Non-adaptive student's activity at a lesson is perceived by them not as a manifestation of intentionality and a student's attitude toward what is happening, but as an annoying hindrance. The choice made on the grounds that do not coincide with the notion of conscious choice is considered erroneous initially. As an erroneous choice it should be corrected and as soon as possible.

Supporters of the "concept of choice", on the contrary, believe that free choice and an educational decision based on it, is a manifestation of subjectness, a fixation of one's own attitude toward teaching, teachers and that is happening at school in sociality. Of course, a simple series of choices is not enough for subjectness development, but a chosen course, a subject and a discipline to some extent change the educational reality of a student. Now it depends on a student, what, with who, at what level and from whom he/she studies. Of course, this is still a weak intention, but since the supporters of the concept of choice see subjectness, they seek, develop and design the methods of work with the student's subjectness with the purpose of its updating, development and complication.

Without noticing subjectness and perceiving it as hostile, the supporters of the concept of selection do not have technological and pedagogical means of developing this very subjectness. As a consequence, the concept of selection at school is manifested in the tendencies towards the extensive increase in hours and a rough differentiation of classes.

Work with subjectness, based on the free choice of students, suggests a complex of intensive pedagogical techniques and a radical change in the educational process model. With the presence of a student's own interest, the pedagogical work effectiveness increases dramatically. 
Let us ask ourselves: why do the vast majority of teachers and administrators "do not see" subjectness and do not trust it? One of the variants of answers is because in their professional and educational life there was little experience of manifesting one's own subjectness. If all my life I was forced to study, then my students are the same as me.

\section{USP vs zone of proximal development}

Neglect of the students' subjectness is manifested in yet another feature of pedagogical cynicism - in ignoring the zone of proximal development. Educational activity is effective if it takes place within the boundaries of this zone: between what a student is able to do on his/ her own and what he/she can do in interaction with other students and/or with the teacher's help. This is very well understood by music and dance teachers as well as other representatives of "secondary subjects". If a student is able to benchpress only the weight bar from the barbell, you cannot give him/her a weight of $45 \mathrm{~kg}$ ! Injuries are almost inevitable! A mathematics teacher knows very well that in the tenth grade some students do not know how to add fractions, but they continue to study the material in accordance to the programme. Curriculum and lesson plans, as well as teaching materials, are becoming more important than the consideration of a zone of proximal development. "They already MUST be able to add fractions! This is what is written! They have already been taught it!"

\section{Prompt vs Error Tolerance}

The cynical "removal" of the contradiction between the zone of proximal development and the USP is often implemented in the form of a prompt. If a student, not understanding what to do, stopped in confusion, or is going to do something wrong, the natural reaction of a pedagogical cynic will be to prompt and correct. Repeating the actions that are above the level of his/her understanding after the teacher, a student "gets to the end". The prompt "has worked". A student still has not understood anything, but the problem is "solved". Prompt's repetition fixes a student's dependent orientation. In a problematic situation, a student is confident that the teacher will correct a task solution and a form tutor will tell you how to conduct the event properly. Prompts are an integral feature of pedagogical cynicism. Error tolerance will presuppose at least distraction of attention, resources and forces to detect, understand and correct it (error). The situation will by grossly distorted by the premeditated course of the "educational process". Management will be lost. It will be necessary to act "according to the situation".

\section{Messiah vs professional}

The word "Teacher" should be written with a capital letter. The Teacher is more than a teacher. Attitudes toward teaching as messianism are another characteristic feature of educational cynicism. In many respects this attitude is, of course, a projection of the figures of "great Teachers". The history of mankind has recorded a whole galaxy of remarkable people who were the Teachers for their followers. The transfer of messianism to one's own status perception in mass education is a way of universal legitimization, a way of reconciliation with one's own "enlightened negativity". The teacher rules symbolically, he/she is responsible for the disciples' fates. The touching stories of grateful students on the Internet are interspersed with "terrible pedagogical stories" about how a school graduate - now a member of the supervising organization came to check the school principal. If a student has become different it is perceived as a pedagogical defeat. What is the cynicism of this mindset? 
Let us ask ourselves: how many teachers teach at school? How many university professors educate one student at the university? We will obtain the classical scheme inversion. In the classical situation of messianism one "guru" has several students. A student at the university has dozens of teachers, some of whom (and sometimes almost all of them) think of themselves as gurus. These several "gurus" claim that these are their values and their way of thinking that should be the determining factor for a student. At the same time, Pyotr Arkadievich is the conspiracy theory supporter, who is suspicious to everything and everyone; Maria Nikandrovna is a devout Catholic, and Sergei Stepanovich is an inveterate liberal. What should a student do? To mimicrate? To ignore the intent of their teachers proposals? Or, finally, choose one and ignore the rest?

From our point of view, the rejection of messianism is a transition to teaching as a professional matter. I declare that I can teach my craft to those who come to me. At the same time I am not a messiah, not a guru, I am a person with my interests, values and meanings. If any of the students consider my values as their own - it is wonderful, but it has nothing to do with my profession. Let us note that this value-semantic variety can be observed among the Hogwarts professors (Rowling, 2000).

\section{Worldview vs educational proposal}

A vivid manifestation of messianism and the desire for symbolic power is a frequently formulated goal - to give children (students) the "worldview". In this case there is a claim that a teacher, no, the Teacher, has a universal knowledge of the world (Mark Kukushin at the conference of "Tutoring in Open Educational Space and Coaching: the Mutual Resources of Two Professions", held in October 2015, ironically remarked: "Tutors differ from coaches by knowing what the world is like"). Sometimes this goal is given to a "collectively distributed entity" - a school or, for example, an education system.

Proclamation and implementation of such a goal is the development of the aforementioned educational cynicism "We know better what they need". A worldview can be different: scientific, truly scientific and modern, but it is always a worldview. False enlightened knowledge thinks of itself as a sort of "Laplace Demon", comprehending (no, has already comprehended!) the secrets of this world and ready to shed the light of truth on ignorant mancubs.

The frenzied desire to "teach all the best that mankind has accumulated" leads to the fact that the volume and complexity of what is proposed increases year by year. It is curious that, according to the standards developers, "the large volume of a complete set of curricula makes the content of the basic general education generally immeasurable" (Development of the Project...).

The genuine scientific, strictly verified and systematic knowledge of how the world is arranged is turned out to be a private worldview, far from being harmonious, based on myths and the fragments of what has been read, heard and seen. In addition to the content of his own discipline, tensor analysis, for example, a professor informs the students what he thinks about women ("who is cleaning the blackboard in such a way, Ivanova, it is not the same as mopping floors"), about the government (here, as a rule, the theory of conspiracy is applied: "they have ruined everything and are proceeding in the same manner"), about the education system ("everything is rotten, the student used to be different") and about science ("There is only one science - physics. As Rutherford said: all the rest is collecting stamps").

What can be an alternative to imposing a holistic worldview on students? A simple thing a proposal to learn what the teacher can do. This 
proposal should be expressed in a simple language that a student understands. Refusing the universal claims to know how "the world is arranged", a teacher should ask him/herself: what, actually, can I myself do properly? What can I teach those who come to me? This is the mechanism for finding the answer to the question that the representatives of educational cynicism do not like - the question of the meaning of studying the subject. The cynical answers that "physics forms a scientific worldview", "mathematics organizes your mind" and "history is necessary for a person in order to know their roots and understand what is happening" have long ceased to be legitimate answers. The evident emptiness of these phrases no longer comforts the souls of both the students and the teachers themselves.

\section{Fear vs interest}

Under conditions of delegitimization of the classical content of education the orientation to use two methods of motivation - the carrot and the stick (fear) prevails in pedagogical practice. It is necessary to punish, frighten and encourage them (school and university students), these are the main incentives for them to master the content that we consider systemic, fundamental and correct. The true interest and the desire to study different aspects are not considered as the leading motives of studying.

The motivational arsenal of educational cynicism is symbolic coercion, symbolic intimidation and symbolic encouragement. As coercion and encouragement work worse and worse, intimidation often becomes the leading "motivator". School students are frightened by the USE (BSE) from the early school age. Students are frightened by the prospect of expulsion. Do not be surprised that the phenomenon of selfeducation is so rare.

Educational cynics are repugnant to the idea that it is necessary to work for the students' interests, needs and desires. The schizoid situation is in the fact that (1) from their own experience they know how much school or university students can do THEMSELVES when they are interested. On the other hand, they (2) see the lack of interest among children to what (and how) they teach. It would seem that from statements (1) and (2) it follows that we need 3a) to understand what can be of interest to children in the zone of their proximal development (the range of possible children's interests); $3 b$ ) to change educational content, to make it differentiated; 3c) to change the methods of working with students.

The schizophrenic logic of educational cynicism derives quite different statements from (1) and (2):

(4a) children should study the proposed and unchangeable content - they will have to pass the USE!

(4b) if they do not want to - they have to be forced!

(4c) these are parents, other teachers (as a rule, high school scolds the secondary school, and the secondary school scolds the primary school), director, government, the Internet and computer games... to blame that they do not want to...

It is interesting that in response to the proposal to understand and take into account the children's interests, educational cynics often exclaim: "Are we supposed to educate consumers?"

Answers 3a-3c suggest that the teacher needs ... to learn a lot. To learn to offer what is interesting. Formulate their education proposal in the students' language (that can be learnt from you). Learn to describe the criteria simply, accurately and explicitly. Learn to create technologies in which as many students as possible can act in their own zone of proximal development. Allow students to choose. Do everything for choice to become the norm. Learn to form a range of interesting proposals. Learn how to form ranges 
of training products, increasingly complex and more interesting.

Let us venture to suggest that one of the reasons for the formal teachers' attitude to improve their skills is precisely their universalist claims. The Guru does not learn from anyone. The one who knows how the world is arranged, who sets the formation of an integral worldview as his goal, is self-sufficient! The Teacher cannot have teachers.

\section{"Sit down, two" vs credit system}

A characteristic feature of educational cynicism is rejecting the systems of educational results objectivization. School teachers and university professors got used to using "magic grading" system. "Sit down, Ivanov, two!" "Today only four, Petrova" - these simple phrases allow them to maintain their own symbolic power. Their "symbolic power" is in assessment. To make the assessment transparent, to subject the result of their own work to pedagogical analytics means "to reveal secret knowledge". Assessment objectivization means that a student can compare the credit points that a teacher has given him with the criteria on which these points are based. $\mathrm{He} /$ she, a student, may not agree with the assessment. $\mathrm{He} / \mathrm{she}$ can assess him/herself (or ask another person to do it).

Educational cynics do not want to share power. That is why they criticize the USE, the BSE and credit systems. When the results and criteria are formulated by others - this is what they do wrong. "These are the wrong results and the wrong criteria". The proposal to develop criteria independently is followed by another schizophrenic response: "We were not taught this!".

\section{Teachers vs programmers}

The enlightened negativism of educational cynics and the schizoid nature of cynical logic require an answer to the question "Who is to blame?" Who is, actually, the enemy? There must be a reason why I, the enlightened Teacher, find myself in a situation of insoluble contradictions? Somebody has created this situation.

The first enemy of the modern educational cynic is the programmer. "These are they, devils, who created social networks, computer games and the Internet". Both school and university students spend hours in front of computer, play games, communicate using chats or use sms messages, post (ugh!) their photos. They are addicted to Warcraft, but not addicted to trigonometry. Away with Warcraft!"

The Internet has made information (quicklyor easily-) accessible. The Internet has really become the "third world". Work on the Internet poses the problem of choosing adequate and proven information from millions of sources. There is a lot of information, it is easily accessible and it has depreciated. A book, TV commercial, a phrase about a film, a famous person's blog, an sms from a friend and a post in a social network all these are equal and alignable sources of information. Lectures and lecture notes are in the same list.

The availability of information, content and software prioritize the "interest in something". If interested, you can do almost anything. The question is that you are interested in.

In the struggle for souls, attention and interest and school and university students' motivations, programmers beat teachers. They think of the user more than anyone else. They create interactive and user-friendly content. They create software products that train the user. They are used to think about what the user will think and do. About how he/she will think and what he/ she can do.

A $7^{\text {th }}$ form student can independently master a computer programme on engineering graphics and design a house for his uncle's garden patch. 
$\mathrm{Hi} /$ she spends hours in front of computer screen, trying to pass the $12^{\text {th }}$ level of a quest, solving rather complex open type tasks. Actually, programmers accustom children to the fact that they are constantly being offered to develop, offering more and more interesting and complex tasks for solution.

\section{Teachers vs officials and parents}

Everything bad in education for the educational cynic is personified. These can be real persons: the Minister of Education Petrov (the name is fictitious), the Head of the Department of Education Ivanova and the school principal Sidorov. These are them, these persons who have ruined education.

I will provide an interesting example. N.A. Kuznetsov, Ph.D., Doctor of Science, Professor and teacher in higher education brought a portrait of the latest Minister of Education to one of his lectures in the philosophy of education at the advanced training courses. He said that this portrait hangs over his desk like a kind of "anti-icon" - he must remember who the enemy of education is! Who is his, Kuznetsov's personal enemy!

Frequently, the enemies of the educational cynic have an impersonal representation. First of all, these are parents, then the underlying education system. University professors accuse school of training for the USE and, herewith, it does not develop the ability to think (at the same time accusing the government that it introduced the USE and is not going to cancel it). Primary school teachers blame kindergartens for poorly preparing their pupils for school.

The teacher is surrounded by enemies. These are they, programmers, officials and parents, who have changed this world, the view of which the teacher gives to children. The worldview turns out to be inconsistent with the reality; the vision of the world is partial. "The student is different now". "They are not interested in anything; they are uncivilized dependents who do not want anything". This happened because the "enemies" have changed the world. A cynical conclusion: we must bring everything back. "Forward to the past!" To the golden eighties, seventies, ... "If the world has changed, if I, the Teacher, do not conform to this world, or rather say, it does not fit me - I will not "cave in to the changing world". If the children have changed, I will teach them the same way as in the golden eighties. Nonsense, that they are not interested!"

\section{Candidate's dissertation vs case study experience}

Another twist of educational cynicism is the established nature of the relationship between pedagogical science and practice. If most school teachers and university professors proudly declare "We are not theoreticians, we are practitioners!", then there is the reverse mindset, which is supported by some representatives of pedagogical science: "We are not practitioners, we are theoreticians!"

Let us ask a simple question: how many teachers of pedagogics, candidates and doctors of pedagogical sciences teach children and preschool children? I could not find official statistics. There is one thing that I can state: the situation when a graduate student, a candidate or a doctor of pedagogical sciences or a person who teaches pedagogical disciplines is not engaged in practical pedagogical activity, but studies it and tells students about it, is frequent. The university lecturer in "methods of teaching physics" teaches students, but he/she is not engaged into the craft that he/she talks about - does not teach physics to the general education school students.

A graduate of a pedagogical university who has not worked with children for a long period of time (so long that it is possible to speak about the results of his/their pedagogical activity), 
enters a postgraduate course and starts studying educational reality without being its actor. No wonder that a significant part of candidate and doctoral dissertations in pedagogy is written in the framework of empirical-analytical methodology. The tradition of post-Soviet pedagogical science greatly contributes to this as well. Even if a real pedagogical experiment is being conducted, it is conducted not by the author of the research itself, but by some attracted teachers. The dissertation author often describes not his/her own pedagogical experience, but the results of observations over the work of these teachers, who are not co-authors of the study, but "the object of observation". Precedent descriptions of their own pedagogical experience are rare in pedagogical studies. For example, when preparing the first allRussian competition "Tutor of the Year", we tried to find "tutorial stories" - a precedent description of the real experience of tutoring of a specific teenager in various sources. Alas!

Such a state of affairs forms a special communicative style of communication between "theorists" and "practitioners". A special language is being formed - something intermediate between the languages of dissertations and reports at the meeting and conversations in the teachers' room.

And another remark. Theorists of pedagogical knowledge, who have never taught at school, are reliably protected by the power status: academic degree and academic title. To get these statuses, it is necessary to work hard. But ... the procedure and the results of the candidate's dissertation defense in pedagogy will not tell us anything about whether an applicant can manage the class, is he/she able to implement the individualization of the educational process in a real school, is he/she able to organize a project office, can he/she find an approach in the third form of an ordinary school to a girl who had previously studied at the Montessori school and, having got into an unusual environment became withdrawn (I am grateful to T.M. Kovaleva for the last example).

\section{Hierarchy vs workshop}

The state of affairs described in the previous section builds a characteristic hierarchy of pedagogical knowledge, described, for instance, in the works by V.V. Kraevsky. The pedagogical methodology is "a system of knowledge about the foundations and the structure of the pedagogical theory, the principles and methods of obtaining knowledge that reflect pedagogical activity, as well as the system of activities for obtaining such knowledge and substantiating programs, logic, methods, and assessing the quality of research work" (Kraevsky, 2002: 7). Pedagogical research is subordinated to methodological pedagogical knowledge. Pedagogy studies educational activity and standardizes it in accordance with its laws, principles and theories. The difference between the theoretical and methodological culture of a scholar and a teacher, according to Kraevsky, lies in the fact that "the first one received scientific pedagogical knowledge and "produces" it, and the latter uses it" (Kraevsky, 2002: 9).

Pedagogical knowledge in this view is arranged hierarchically. The analysis of social relations in education even allows increasing the number of levels: philosopher - methodologist theorist - methodologist - deputy head teacher - teacher. It is supposed (seems) that each higher level is prescriptive in relation to the underlying one. It seems because, as has already been mentioned, philosophers-theoristsmethodologists seldom work with children systematically. It seems because methodologist, deputy head teachers and teachers, as a rule, do not read dissertations and monographs of their scientific leaders.

The situation is made even worse by the fact that in the modern education, including in 
Russia, many philosophical and pedagogical concepts coexist. Authors of various scientific schools create their own hierarchies. These hierarchies are supported by "their" dissertation councils and their conferences. These scientific and pedagogical neo-tribes do not agree well with each other. Textbook on pedagogy, written by one of the leaders are zealously criticized by the representatives of another tribe.

Under these conditions, reasonable questions may arise for the representatives of innovative pedagogy and for those who share the ideas of individual education. Is it worth trying to integrate into the hierarchical system of social relations, built in accordance with the principles of educational cynicism? Is the apparatus of dissertations on pedagogy adequate for theoretical comprehension of innovative pedagogical practice? Can the attempt to "build in" lead to the fact that the representatives of innovative pedagogy themselves internalize the natural attitudes of educational cynicism?

We are convinced that the ideas of individualizing education require fundamentally different communicative mechanisms that overcome the dissociation of "theorists and practitioners" from their carriers. One of such mechanisms can be mutual educational practice, over which reflexive and methodological discourse - an educational workshop is built. If there is no way to escape hierarchy, a hierarchy of another type - the pedagogical skill hierarchy can be built in such practices.

\section{References}

Andreeva, N. (2016). Krizisy motivatsii i smeshannoe obuchenie [Motivation Crises and Blended Learning]. Available at: https://newtonew.com/discussions/motivation-in-blended-learning

Development of the Project of Fundamental Core for Basic General Education. Available at: http://ru.convdocs.org/docs/index-194378.html

Habermas, J. (2000). Moral'noe soznanie i kommunikativnoe deistvie [Moral Consciousness and Communicative Action]. SPb, Nauka, $126 \mathrm{p}$.

Kraevsky, V.V. (2002). Metodologiia pedagogiki: proshloe i nastoiashchee [Methodology of Pedagogy: the Past and the Present], in Pedagogy, (1), 3-10.

Rowling, J.K. (2000). Garry Potter i filosofskii kamen' [Harry Potter and the Sorcerer's Stone]. Moscow, ROSMEN.

Sloterdijk, P. (2009). Kritika tsinicheskogo razuma [Critique of Cynical Reason], transl. from German by A. Pertsev. Ekaterinburg, U-Fakroria, M., AST MOSKVA. 


\section{Критика педагогического цинизма}

\section{B.P. Имакаев}

Пермский государственный национальный исследовательский университет Россия, 614990, Пермь, ул. Букирева, 15

Статья посвящена исследованию феномена педагогического ичинизма - установки «просвещенной негативности», характерной для многих учителей школ и преподавателей вузов. Поскольку эта установка, как правило, проявляется в отрицании, противопоставлении, обвинении, структуру статьи составили бинарные оппозиции, проявляющиеся в словах и действиях представителей нео-племени «педагогических изиников».

Ключевые слова: иинизм и кинизм, телесность и мышление, страх и интерес, теория и практика, отбор и выбор, мессианство и профессионализм, картина мира и образовательное предложение.

Научная спеииальность: 09.00.00 - философские науки. 